\title{
The Novel Compound NO-1886 Increases Lipoprotein Lipase Activity with Resulting Elevation of High Density Lipoprotein Cholesterol, and Long-term Administration Inhibits Atherogenesis in the Coronary Arteries of Rats with Experimental Atherosclerosis
}

Kazuhiko Tsutsumi, * Yasuhide Inoue, * Atsushi Shima, * Kentaro Iwasaki, ${ }^{*}$ Masako Kawamura, ${ }^{*}$ and Toshio Murase

${ }^{*}$ New Drug Research Laboratory, and ${ }^{\ddagger}$ Department of Pathology, Naruto Research Institute, Otsuka Pharmaceutical Factory,

Incorporated, Tokushima, Japan; and ${ }^{\S}$ Department of Endocrinology and Metabolism, Toranomon Hospital, Tokyo, Japan

\begin{abstract}
We have discovered a novel compound, NO-1886, which possesses a powerful lipoprotein lipase (LPL) activity-increasing action. Administration of NO-1886 increased LPL activity in the postheparin plasma, adipose tissue, and myocardium of rats, and produced a reduction in plasma triglyceride levels with concomitant elevation of HDL cholesterol levels. Administration of NO-1886 increased LPL enzyme mass in postheparin plasma and mRNA activity in epididymal adipose tissue, and it was concluded that the mode of action of this compound is stimulation of tissue LPL synthesis. We also conducted longterm studies to assess the impact of increases in LPL activity and HDL levels on the development of atherosclerotic lesions in rats. Administration of NO-1886 for as long as $\mathbf{9 0} \mathrm{d}$ significantly decreased the degree of atherosclerotic changes in the coronary arteries of vitamin $D_{2}$-treated, cholesterol-fed rats. Statistical analysis indicated that increased concentration of HDL is the factor contributing mostly to the prevention of coronary artery sclerosis. In summary, the results of our study indicate that compound NO-1886 increases LPL activity, causing an elevation in HDL levels, and that long-term administration of NO-1886 to rats with experimental atherosclerosis provides significant protection against the development of coronary artery lesions. (J. Clin. Invest. 1993. 92:411-417.) Key words: NO-1886 - lipoprotein lipase $•$ hypertriglyceridemia $\bullet$ high density lipoprotein cholesterol $\bullet$ atherosclerosis
\end{abstract}

\section{Introduction}

Recently there has been increasing evidence of an association between triglycerides and increased risk of coronary heart disease (1). Hypertriglyceridemia per se is an independent risk factor, and this is especially true in certain specific groups of individuals, such as women, those with high plasma LDL (or total) cholesterol levels $(2,3)$, those with low HDL cholesterol, and diabetics $(4,5)$. Thus, a maneuver which would lower plasma triglyceride levels should be of great value in protecting against atherosclerosis. Over the past several years, we have been seeking out compounds that reduce plasma triglyceride

Address correspondence Kazuhiko Tsutsumi, New Drug Research Laboratory, Otsuka Pharmaceutical Factory, Inc., Muya-cho, Naruto, Tokushima, 772 Japan.

Received for publication 3 February 1992 and in revised form 2 February 1993.

J. Clin. Invest.

(C) The American Society for Clinical Investigation, Inc.

0021-9738/93/07/411/07 \$2.00

Volume 92, July 1993, 411-417 levels and have screened compounds synthesized for this purpose.

Hypertriglyceridemia can be caused by either increased synthesis or inadequate removal of triglycerides or both. We hoped to obtain compounds which would increase lipoprotein lipase (LPL) ${ }^{1}$ activity, an enzyme playing a crucial role for triglyceride removal, because such compounds should enhance triglyceride catabolism via the enzyme's catalytic action and lower the plasma triglyceride levels. In addition, since a precursorproduct relationship appears to exist between triglyceride-rich lipoproteins and HDL levels (6), compounds that increase LPL activity are expected to increase HDL levels. Among 100 compounds synthesized in our laboratory, we discovered the compound NO-1886 which has a potent LPL activity-increasing action in rats. In this report, we describe the properties of NO-1886 and its effects on plasma lipids. We were also especially interested in learning whether induction of LPL activity would promote or suppress the development of atherosclerosis. To address this question directly, we administered NO-1886 to rats with experimental atherosclerosis for $90 \mathrm{~d}$ and examined its effect on their coronary arteries histochemically. The experiments revealed that NO-1886 prevents the development of coronary artery sclerosis in animals with experimental model of the disease.

\section{Methods}

\section{Materials}

Agent NO-1886, 4-diethoxyphosphorylmethyl- $N$-(4-bromo-2-cyanophenyl) benzamide was synthesized in the New Drug Research Laboratory of Otsuka Pharmaceutical Factory, Inc., Naruto, Tokushima, Japan. Glycerol tri[ $\left[1-{ }^{14} \mathrm{C}\right]$ oleate $(2.2 \mathrm{GBq} / \mathrm{mmol})$ was obtained from Amersham International, Amersham, United Kingdom, triolein, protamine sulfate, and mineral oil from Sigma Chemical Co., St. Louis, MO, and heparin from Novo, Bajsvaeld, Denmark. Taq DNA polymerase and random primer were obtained from Takara Shuzo Co., Ltd., Kyoto, Japan, RNAase inhibitor from Pharmacia LKB Biotechnology, Uppsala, Sweden, and reverse transcriptase from GIBCO BRL, (Life Technologies, Inc.), Gaithersburg, MD. All other chemicals used were high grade commercially available products.

\section{Animal experiments}

Male Wistar rats weighing 180-200 g were obtained from the Nissin Tokushima Institute for Animal Reproduction, Tokushima, Japan. The animals were maintained under a 12-h light-dark cycle at a constant temperature of $23 \pm 2^{\circ} \mathrm{C}$ and acclimatized for at least $2 \mathrm{wk}$ before the start of the experiment. NO-1886 was suspended in 5\% gum arabic and administered to rats via a gastric tube. Whenever blood samples were collected, the animals were anesthetized with sodium pentobarbital $(50 \mathrm{mg} / \mathrm{kg}$ body weight [BW]).

1. Abbreviations used in this paper: BW, body weight; HTGL, hepatic triglyceride lipase; LPL, lipoprotein lipase. 
Effects of a single dose of NO-1886 in normal rats. Changes in plasma lipid concentrations and LPL activity in postheparin plasma were determined after a single administration of NO-1886 in doses of 3 , 6,12 , and $25 \mathrm{mg} / \mathrm{kg} \mathrm{BW}$ to normal rats. Control animals received $5 \%$ gum arabic, a diluent of NO-1886. Based on the results of a time-course study, blood was collected $4 \mathrm{~h}$ after NO-1886 administration. Without prior fasting, blood samples were drawn from the tail vein into tubes containing $1 \mathrm{mg}$ EDTA $/ \mathrm{ml}$, and plasma isolated using a refrigerated centrifuge was used for lipid determination. The animals were then injected with heparin ( $100 \mathrm{U} / \mathrm{kg} \mathrm{BW}$ ) via the tail vein, and blood samples were collected 5 min later. Plasma samples were used to determine LPL and hepatic triglyceride lipase (HTGL) activity. In some experiments, LPL enzyme mass in postheparin plasma was also measured.

Effects of repeated administration of NO-1886 in normal rats. Three groups of normal rats received NO-1886 in daily doses of 25 $\mathrm{mg} / \mathrm{kg} \mathrm{BW}$ for 2,4 , and $8 \mathrm{~d}$, respectively, and control animal experiments were run parallel with the experimental group. Blood samples and samples after heparin injection were collected in the same way as described above. In an attempt to measure LPL activity in both adipose tissue and myocardium, we performed another set of experiments in which no heparin was administered.

Long-term administration of NO-1886 to rats with experimental atherosclerosis. Male Wistar rats, aged $7 \mathrm{wk}$ and weighing 180-200 g, were divided into four groups, a normal control group and three atherogenic diet-fed groups. Normal control rats were fed a standard laboratory chow. The atherogenic diet-fed animals were further divided into $(a)$ controls and rats treated with either $(b)$ low dose (daily dose of 3 $\mathrm{mg} / \mathrm{kg} \mathrm{BW}$ throughout the experimental period) or (c) high dose (30 $\mathrm{mg} / \mathrm{kg} \mathrm{BW}$ ) NO-1886. These three groups of rats were given oral vita$\min \mathrm{D}_{2}$ in a daily dose of $350,000 \mathrm{U} / \mathrm{kg} \mathrm{BW}$ for the initial $4 \mathrm{~d}$ and subsequently fed a standard laboratory chow supplemented with $2 \%$ cholesterol, $0.5 \%$ cholic acid sodium salt, and $0.2 \%$ 6-methyl-2-thiouracil for up to $90 \mathrm{~d}(7,8)$. The animals were given free access to food and tap water. Food consumption was measured daily, and body weight was recorded weekly. At the end of the experimental period, the animals were killed by exsanguination under sodium pentobarbital anesthesia. Blood samples were collected from the posterior vena cava for lipid measurements. The hearts were removed immediately and passed in blind fashion to the pathologist for histological examination. The heart was divided longitudinally into two halves from the ascending aorta to the apex. The ascending aorta, septum, and right and left ventricles were exposed on the cut surfaces. The materials were fixed in $10 \%$ neutral buffered formalin, and embedded in paraffin. Thin sections $(4 \mu \mathrm{m})$ obtained were stained with hematoxylin and eosin, alcian blue for acid-mucopolysaccharide determination, and by von Kossa's method to determine calcium. Frozen sections were also stained with oil red 0 for lipid determination. More than 10 coronary arteries, both right and left coronary arteries and their branches, could be identified on the cut surfaces of each section. All of the coronary arteries on the sections were examined histopathologically.

\section{Analytical methods}

Plasma lipids. Plasma total cholesterol, HDL cholesterol, and triglycerides were determined by conventional enzymatic methods. The cholesterol C-test Wako (Wako Pure Chemical Industries, Osaka, Japan) was used in the case of cholesterol, the Nescote HDL-C kitN (heparin calcium precipitation; Nippon Shoji, Osaka, Japan) for HDL cholesterol and the triglyceride G-test Wako (Wako Pure Chemical Industries) for triglycerides.

Plasma lipoprotein analysis. Ultracentrifugation of plasma lipoproteins was carried out using a rotor (L42T; Hitachi Koki Co., Ltd., Tokyo, Japan). The density of the samples was adjusted with $\mathrm{KBr}$ and $\mathrm{KBr}$ solutions of known density. Plasma samples $(100 \mu 1)$ were ultracentrifuged at densities of $1.006,1.019,1.063$, and $1.125 \mathrm{~g} / \mathrm{ml}$, respectively, and the lipid concentration of each fraction was measured (9). The lipid levels of five lipoprotein fractions were calculated: VLDL, $d$
$<1.006 \mathrm{~g} / \mathrm{ml}$, intermediate density lipoprotein, $d 1.006-1.019$, LDL, $d$ 1.019-1.063), $\mathrm{HDL}_{2}, d$ 1.063-1.125), and $\mathrm{HDL}_{3}, d>1.125$.

Measurement of LPL activity and mass in postheparin plasma. LPL activity in postheparin plasma was measured by an immunochemical method described previously $(10)$ using glycerol tri $\left[1-{ }^{14} \mathrm{C}\right]$ oleate as substrate and selective blocking of hepatic lipase activity with antiserum to rat hepatic lipase. HTGL activity in postheparin plasma was obtained by subtracting LPL activity from total plasma lipase activity. LPL enzyme mass was measured by sandwich ELISA using polyclonal antibodies raised against human LPL, as described previously (11).

Tissue LPL activity. Myocardial LPL activity was measured as reported previously (12). A specimen of myocardium was homogenized in $50 \mathrm{mM} \mathrm{NH}_{4} \mathrm{OH}-\mathrm{NH}_{4} \mathrm{Cl}$ buffer ( $\mathrm{pH} \mathrm{8.5)} \mathrm{containing} \mathrm{heparin} \mathrm{for} 60$ min at $0^{\circ} \mathrm{C}$. The suspension was then centrifuged, and the supernatant was used to measure LPL activity. Adipose tissue LPL activity was measured as described earlier (13). A specimen of epididymal adipose tissue weighing $100 \mathrm{mg}$ was minced into small pieces and placed in Krebs-Ringer bicarbonate buffer ( $\mathrm{pH} \mathrm{7.4)}$ in the presence of heparin for $60 \mathrm{~min}$ at $37^{\circ} \mathrm{C}$. The incubation medium was then assayed for LPL activity (heparin-releasable LPL). In some experiments, the residual LPL activity in the adipose tissue was also measured (tissue-bound, heparin-extractable LPL) (14) to determine total LPL activity in the tissue.

RNA preparation and Northern analysis. Total RNA samples were prepared from rat epididymal adipose tissue by an acid guanidium thiocyanate-phenol chloroform extraction method (15). Agarose gel electrophoresis of RNA and Northern blotting were carried out by the method described by Sambrook et al. (16). The two molecular probes for the Northern blotting were prepared by reverse transcription and subsequent PCR as follows. First, the mixture of $5.0 \mu \mathrm{g}$ of total RNA obtained from rat adipose tissue and $200 \mathrm{pmol}$ of random primer in a final vol of $5.0 \mu \mathrm{l}$ was denaturated at $70^{\circ} \mathrm{C}$ for $3 \mathrm{~min}$ and cooled on ice. The synthesis of the first strand of cDNA was initiated by the addition of $5.0 \mu \mathrm{l}$ of premixture containing $100 \mathrm{mM}$ Tris- $\mathrm{HCl}$ buffer, $\mathrm{pH} 8.3$, $148 \mathrm{mM} \mathrm{KCl}, 6 \mathrm{mM} \mathrm{MgCl} 2,2 \mathrm{mM}$ dNTP, $20 \mathrm{mM}$ DTT, $16.5 \mathrm{U}$ of RNase inhibitor, and $100 \mathrm{U}$ of reverse transcriptase. This mixture was incubated at $37^{\circ} \mathrm{C}$ for $1 \mathrm{~h}$, and the reverse transcriptase was denaturated by heating at $98^{\circ} \mathrm{C}$ for $10 \mathrm{~min}$. A $1.0-\mu$ laliquot of this mixture was used directly as the PCR template. The PCR mixture $(100 \mu \mathrm{l})$ contained $1.0 \mu \mathrm{l}$ of template, $100 \mathrm{pmol}$ of each primer, $10 \mathrm{mM}$ Tris $-\mathrm{HCl}$ buffer, $\mathrm{pH} 8.3,50 \mathrm{mM} \mathrm{KCl}, 1.5 \mathrm{mM} \mathrm{MgCl}{ }_{2}, 1.6 \mathrm{mM} \mathrm{dNTP}$, and 2.5 units of Taq DNA polymerase. After overlaying the reaction mixture with $50 \mu \mathrm{l}$ of mineral oil, amplification was performed under the standard conditions for PCR (16). To obtain the putative cDNA fragment encoding rat LPL by PCR, two synthesized oligonucleotides, 5'CGAAGTATTGGGATCCAGAAAC and 5'-CTTTCACTCGGATCCTCTCGAT, were used as the downstream and upstream primer, respectively. These primers correspond to position $655-676$ and position 1303-1282 on mouse LPL cDNA (in this paper, the nucleotide sequences were numbered by defining the translation initiation site as $+1)$. The cDNA fragment obtained (649 bp) was subcloned into pBLUESCRIPT (Stratagene Inc., La Jolla, CA), and its nucleotide sequence was determined by the chain-termination method. We confirmed that the nucleotide sequences of the cDNA fragment obtained ( $649 \mathrm{bp}$ ) and the cDNA encoding mouse LPL were highly homologous (93.7\%). To obtain the putative rat $\beta$-actin cDNA fragment, the downstream primer (5'-ATGGATGACGATATCGCTGCG) and the upstream primer (5'-GTGCCTAGGGCGGCCCACGAT) were used for PCR. These primers correspond to position 1-22 and position 120100 on rat $\beta$-actin cDNA, respectively. The nucleotide sequence of the cDNA fragment obtained ( $120 \mathrm{bp}$ ) was identical to the $1-120$ region on the cDNA encoding rat $\beta$-actin where it has low homology with $\alpha$-actin. These cDNA fragments were radiolabeled by the multipriming method and used for Northern blotting.

\section{Statistical analysis}

The results are expressed as means $\pm \mathrm{SD}$. Comparisons between two groups were analyzed for statistical significance by Student's $t$ test or 

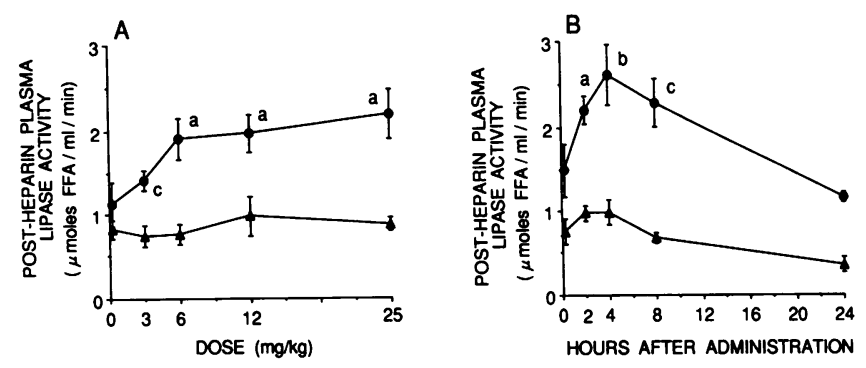

Figure 1. Postheparin plasma LPL and HTGL activity in NO-1886treated normal rats. $(A)$ Dose relationship: NO-1886 was administered to rats, and $4 \mathrm{~h}$ later the rats were injected with heparin ( 100 $\mathrm{U} / \mathrm{kg}$ body wt) via the tail vein. Blood samples were collected $5 \mathrm{~min}$ later, and LPL and HTGL activity in postheparin plasma were measured, as described previously (10). (B) Time-course study: changes of post-heparin plasma LPL $(\bullet)$ and HTGL $(\Delta)$ activity in relation to elapsed time after administration of NO-1886, $25 \mathrm{mg} / \mathrm{kg}$ body $\mathrm{wt}$.

Data are expressed as means $\pm \operatorname{SD}(n=6)$. Significantly different from the respective values in control rats: ${ }^{\mathrm{a}} P<0.001,{ }^{\mathrm{b}} P<0.01,{ }^{\mathrm{c}} P<0.05$.

Aspin-Welch's $t$ test. Comparisons among more than two groups were analyzed using the one way analysis of variance, followed by the Dannett's test. Multiple regression analysis was used to evaluate the relationship between coronary artery sclerosis and protective factors. Statistical calculations were performed on a FACOM M-760/40 computer (Fujitsu Ltd., Tokyo, Japan) using the program ANALYST (Fujitsu Ltd.).

\section{Results}

\section{Effects of a single dose of NO-1886 in normal rats}

Postheparin plasma LPL activity and mass. Single doses of NO-1886 caused a significant increase in postheparin plasma LPL activity in normal rats. The increases were dose dependent in the $0-25 \mathrm{mg} / \mathrm{kg} \mathrm{BW}$ range (Fig. $1 \mathrm{~A}$ ). The increase peaked 4 $h$ after NO-1886 administration and declined thereafter returning to the baseline level after $24 \mathrm{~h}$ (Fig. $1 B$ ). Single dose of NO-1886 had no effect on postheparin plasma HTGL activity (Fig. 1). The question arises as to whether NO-1886 itself enhances LPL activity rather than increasing tissue LPL. To resolve this matter, we added NO-1886 in concentrations of $10^{-4}$ $\mathrm{M}-10^{-6} \mathrm{M}$ to plasma samples collected after heparin administration and measured lipase activities. The in vitro addition of NO-1886 failed to produce any enhancement in LPL activity.

Administration of NO-1886 in a dose of $25 \mathrm{mg} / \mathrm{kg} \mathrm{BW}$ caused an increase of LPL mass in postheparin plasma, which

Table I. LPL Enzyme Mass in the Postheparin Plasma of N0-1886-treated Normal Rats

\begin{tabular}{lccc}
\hline & & LPL mass & LPL activity \\
\hline & $n$ & $U / m l$ & $\mu m o l ~ F F A / m l$ per $\min$ \\
Control & 5 & $5.59 \pm 0.22$ & $1.54 \pm 0.06$ \\
N0-1886 & 5 & $6.53 \pm 0.10^{*}$ & $1.93 \pm 0.09^{*}$ \\
& & & \\
\hline
\end{tabular}

N0-1886 was administered to normal rats in a dose of $25 \mathrm{mg} / \mathrm{kg} \mathrm{BW}$ and $4 \mathrm{~h}$ later the rats were injected with heparin (100 U/ $\mathrm{kg} \mathrm{BW})$ via the tail vein. Blood samples were collected 5 min later. Plasma samples were used to measure LPL enzyme mass, as well as LPL activity. $1 \mathrm{U}$ corresponds to $100 \mathrm{ng}$ of human LPL. Data are expressed as means \pm SD. Significantly different from the value in the respective control rats: ${ }^{*} P<0.001$.
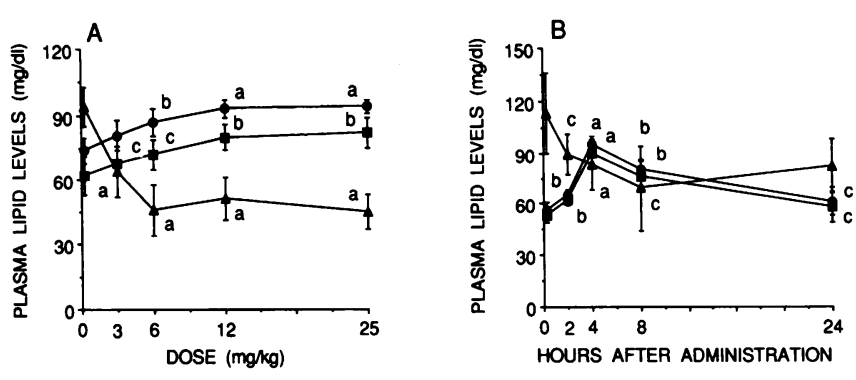

Figure 2. Plasma lipid levels in NO-1886-treated normal rats. $(A)$ Dose relationship: NO-1886 was administered to rats. Blood samples were collected $4 \mathrm{~h}$ later, and plasma lipids were measured. $(B)$ Timecourse study: changes of plasma cholesterol $(\bullet), \mathrm{HDL}$ cholesterol $(\bullet)$, and triglycerides $(\Delta)$ in relation to elapsed time after administration of NO-1886, $25 \mathrm{mg} / \mathrm{kg}$ body wt. Significantly different from the respective values in the control rats: ${ }^{\mathrm{a}} P<0.001,{ }^{\mathrm{b}} P<0.01,{ }^{\mathrm{c}} P$ $<0.05$.

was $17 \%$ higher than control rats $(P<0.001)$. The degree of increase of LPL mass was very similar to that of enzyme activity (Table I).

Plasma lipids. Single doses of NO-1886 to normal rats were followed by significant decreases in plasma triglyceride levels with concomitant increases in HDL cholesterol. Plasma triglycerides fell to their lowest levels in response to $6 \mathrm{mg} / \mathrm{kg} \mathrm{BW}$ of NO-1886, while HDL cholesterol levels rose as the dose of NO1886 was increased to $25 \mathrm{mg} / \mathrm{kg} \mathrm{BW}$ (Fig. 2). The changes in both triglyceride and HDL cholesterol levels were associated with changes in postheparin plasma LPL activity. This experiment revealed a significant increase in total cholesterol concentrations in the experimental animals (Fig. 2).

Further analysis by ultracentrifugation showed that the cholesterol in the LDL fraction did not change and that the in-

Table II. Lipid Levels in the Plasma Lipoprotein Fractions of N0-1886-treated Normal Rats

\begin{tabular}{lcc}
\hline \multicolumn{1}{c}{ Composition } & Control & N0-1886-treated \\
\hline Cholesterol $(m g / d l)$ & & \\
Total & $52.1 \pm 6.3$ & $76.2 \pm 5.4^{*}$ \\
VLDL & $5.6 \pm 1.5$ & $5.7 \pm 2.2$ \\
IDL & $\mathrm{ND}$ & $\mathrm{ND}$ \\
LDL & $7.4 \pm 2.4$ & $7.9 \pm 3.0$ \\
HDL & $35.4 \pm 5.2$ & $57.6 \pm 5.0^{*}$ \\
HDL & $1.6 \pm 0.8$ & $1.4 \pm 0.1$ \\
Triglyercides $(m g / d l)$ & & \\
Total & $121.2 \pm 19.4$ & $51.3 \pm 6.2^{*}$ \\
VLDL & $102.8 \pm 11.4$ & $41.4 \pm 5.7^{*}$ \\
IDL & $4.7 \pm 2.4$ & $2.4 \pm 1.4^{*}$ \\
LDL $_{\text {HDL }}$ & $11.0 \pm 7.5$ & $5.4 \pm 1.8$ \\
HDL & $\mathrm{ND}$ & $\mathrm{ND}$ \\
& $\mathrm{ND}$ & $\mathrm{ND}$ \\
\hline
\end{tabular}

N0-1886, $25 \mathrm{mg} / \mathrm{kg} \mathrm{BW}$, was administered to normal rats. Blood samples were collected $4 \mathrm{~h}$ after N0-1886 administration, and plasma lipoproteins were analyzed by ultracentrifugation. Recovery rates of cholesterol and triglycerides were 96 and $97 \%$, respectively. Data are expressed as means \pm SD $(n=7)$; ND, not detectable. Significantly different from the value in the respective control rats: ${ }^{*} P<0.001$. 

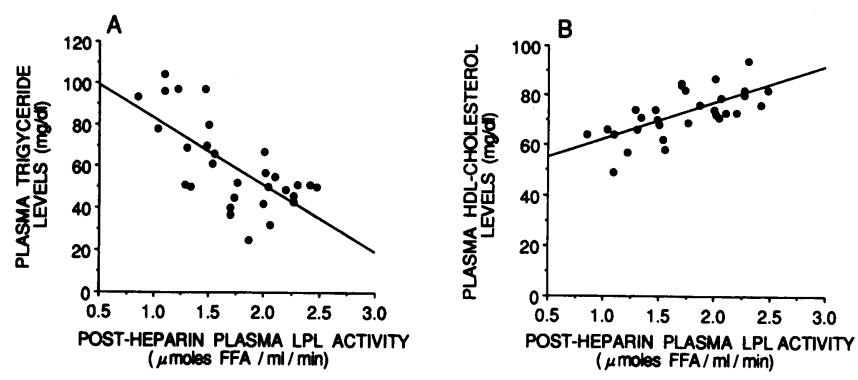

Figure 3. Relationship between postheparin plasma LPL activity and $(A)$ triglycerides and $(B)$ HDL cholesterol levels.

crease in plasma total cholesterol was primarily a reflection of an increase in the HDL cholesterol fraction (Table II).

Plasma lipids in relation to postheparin plasma LPL activity. The relationship between preheparin triglyceride and HDL cholesterol levels in plasma and LPL activity in postheparin plasma was assessed in experimental animals given different doses of NO-1886. As shown in Fig. 3, plasma triglyceride levels were inversely correlated with LPL activity $(r=-0.686, P$ $<0.01, n=30$ ), while HDL cholesterol levels were positively correlated with the activity of the enzyme $(r=0.678, P$ $<0.01$ ). To further demonstrate that the increase in LPL activity elevated HDL cholesterol levels directly, an experiment was performed in which protamine sulfate was used to block the rise in LPL activity (17) in response to administration of NO1886. Prior intravenous protamine sulfate, $25 \mathrm{mg}$ dissolved in saline $/ \mathrm{kg} \mathrm{BW}$, inhibited both the rise in HDL cholesterol and the fall in plasma triglyceride levels, both of which were always induced by the compound (Table III).

\section{Effects of repeated administration of NO-1886 in normal rats}

Plasma and tissue lipase activities. Daily administration of NO-1886 to normal rats caused a significant increase in postheparin plasma LPL activity, while HTGL activity in postheparin plasma remained unchanged (Fig. 4). The LPL activity of epididymal adipose tissue rose gradually and $8 \mathrm{~d}$ later the activity of the NO-1886-treated rats was 2.7 times higher than that of controls (Fig. $5 \mathrm{~A}$ ). Myocardial LPL activity was 1.4 times

Table III. Effects of Prior Administration of Protamine Sulfate on Plasma Lipids in N0-1886-treated Rats

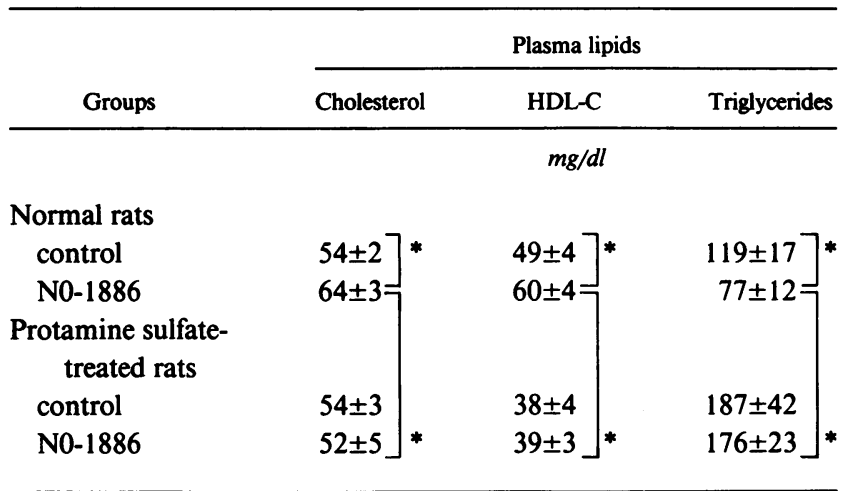

Protamine sulfate, $25 \mathrm{mg} / \mathrm{kg} \mathrm{BW}$, was administered to rats via the tail vein. $5 \mathrm{~min}$ later, N0-1886 was administered in a dose of $25 \mathrm{mg} / \mathrm{kg}$ BW and $2 \mathrm{~h}$ later blood was drawn to measure plasma lipids. Data are expressed as means $\pm \operatorname{SD}(n=7)$. Significantly different from the value in the respective normal rats treated with N0-1886: ${ }^{*} P<0.001$.
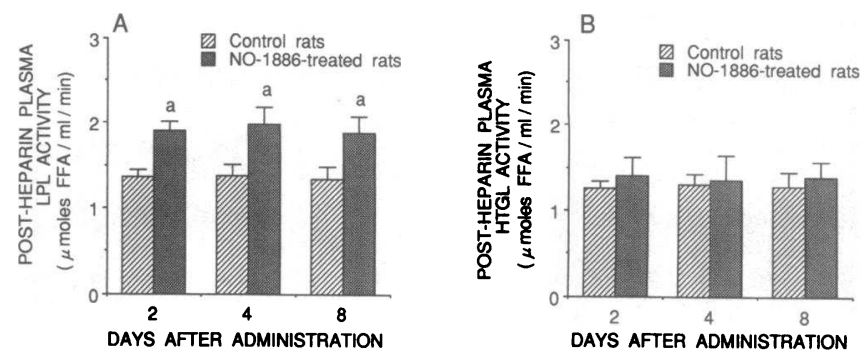

Figure 4. Postheparin plasma lipases of normal rats after repeated administration of NO-1886. ( $A$ ) LPL. $(B)$ HTGL. NO-1886 was administered to normal rats in a daily dose of $25 \mathrm{mg} / \mathrm{kg}$ BW for 2,4 , and $8 \mathrm{~d}$. Postheparin plasma was collected $4 \mathrm{~h}$ after the final dose. Data are expressed as means $\pm \mathrm{SD}(n=6)$. Significantly different from the respective values in the control rats: ${ }^{a} P<0.001$.

higher in the NO-1886-treated rats than controls (Fig. 5 B). In another set of experiments, we measured both heparin-releasable and tissue-bound heparin-extractable LPL in adipose tissue. The activities of both fractions of LPL were higher in the NO-1886 treated rats than in the controls (Table IV).

Plasma lipids. Changes in plasma triglyceride and HDL cholesterol levels after repeated administration of NO-1886 are shown in Fig. 6. Plasma triglyceride levels had fallen by $52 \%$ and plasma HDL cholesterol levels risen by $37 \% 8 \mathrm{~d}$ later.

Effect of NO-1886 on the expression of LPL in epididymal adipose tissue

LPL expression was enhanced $4 \mathrm{~h}$ after administration of NO1886. As shown in Fig. 7, the amount of mRNA encoding LPL was increased by NO-1886 in a dose-dependent manner. Image analysis of the autoradiograph by particle analysis indicated that NO-1886 in doses of 25 and $100 \mathrm{mg} / \mathrm{kg} \mathrm{BW}$ increased the amount of mRNA 3.2- and 5.1-fold, respectively, compared with the controls. On the other hand, the average amount of
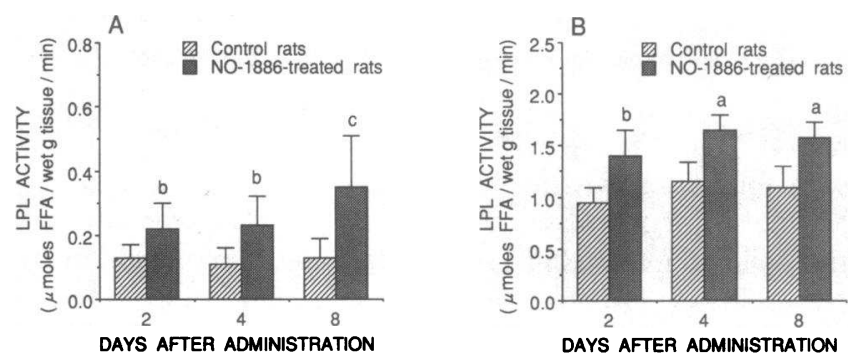

Figure 5. Tissue LPL activity of normal rats after repeated administration of NO-1886. $(A)$ Adipose tissue LPL activity. $(B)$ Myocardial LPL activity. NO-1886 was administered to normal rats in a daily dose of $25 \mathrm{mg} / \mathrm{kg} \mathrm{BW}$ for 2, 4, and $8 \mathrm{~d}$. Epididymal adipose tissue and myocardium were removed $4 \mathrm{~h}$ after the final dose. Adipose tissue LPL activity was measured as described previously (13). A specimen of adipose tissue weighing $100 \mathrm{mg}$ was minced into small pieces, placed in $1 \mathrm{ml}$ of Krebs-Ringer bicarbonate buffer, pH 7.4, containing $40 \mathrm{mg}$ of BSA and $1.8 \mathrm{mg}$ of glucose, and incubated in the presence of heparin $(2 \mathrm{U} / \mathrm{ml})$ for $60 \mathrm{~min}$ at $37^{\circ} \mathrm{C}$. The incubation medium was then assayed for LPL activity. Myocardial LPL activity was measured as reported previously (12). A specimen of myocardium weighing $200 \mathrm{mg}$ was homogenized in $1 \mathrm{ml}$ of $50 \mathrm{mM} \mathrm{NH}_{4} \mathrm{OH}-$ $\mathrm{NH}_{4} \mathrm{Cl}$ buffer ( $\mathrm{pH} 8.5$ ) containing $0.5 \mathrm{U} / \mathrm{ml}$ heparin on ice for 60 min. The suspension was then centrifuged, and the supernatant was assayed for LPL activity. Data are expressed as means $\pm \operatorname{SD}(n=6)$. Significantly different from the respective values in the control rats: ${ }^{\mathrm{a}} P<0.001,{ }^{\mathrm{b}} P<0.01,{ }^{\mathrm{c}} P<0.05$. 
Table IV. Effect of N0-1886 on Heparin-releasable and Tissuebound Heparin-extractable LPL in the Adipose Tissue of Rats

\begin{tabular}{|c|c|c|c|}
\hline & $\begin{array}{c}\text { Heparin-releasable } \\
\text { LPL }\end{array}$ & $\begin{array}{l}\text { Tissue-bound heparin- } \\
\text { extractable LPL }\end{array}$ & $\begin{array}{l}\text { Total LPL } \\
\text { activity }\end{array}$ \\
\hline & \multicolumn{3}{|c|}{$\mu \mathrm{mol} F F A /$ min per wet $\mathrm{g}$ tissue } \\
\hline Control & $0.205 \pm 0.051$ & $0.215 \pm 0.035$ & $0.420 \pm 0.082$ \\
\hline N0-1886 & $0.462 \pm 0.121^{*}$ & $0.339 \pm 0.093^{\ddagger}$ & $0.800 \pm 0.209^{\S}$ \\
\hline
\end{tabular}

N0-1886 was administered to normal rats in a daily dose of $25 \mathrm{mg} / \mathrm{kg}$ BW for $4 \mathrm{~d}$. Epididymal adipose tissue was removed $4 \mathrm{~h}$ after the final dose, and two distinct fractions of LPL, i.e., heparin-releasable and tissue-bound heparin-extractable fractions, were measured. Heparin-releasable LPL was measured as described in the legend of Fig. 5. After collection of heparin-releasable LPL, acetone/ether-dried powder of adipose tissue was prepared. The residual LPL in the tissue was extracted and measured according to a modification of the method of Salaman and Robinson (16). Data are expressed as means $\pm \operatorname{SD}(n=6)$. Significantly different from the value in the respective control rats: ${ }^{*} P<0.001,{ }^{\ddagger} P<0.05,{ }^{\S} P<0.01$.

mRNA encoding $\beta$-actin was very similar in all three groups. These findings suggest that NO-1886 increases the amount of LPL protein by enhancing transcription and/or stabilization of the mRNA encoding LPL.

\section{Effects of long-term administration of NO-1886 on experimental atherosclerosis in the rat}

The experiment was performed twice, and each result was combined. There were no differences in body weight gain ( $\mathrm{Ta}$ ble $\mathrm{V}$ ) and food consumption between NO-1886 treated rats and controls.

Plasma lipids. Rats with experimental atherosclerosis exhibited a marked increase in plasma cholesterol. Administration of NO-1 886 to rats fed an atherogenic diet increased HDL cholesterol and decreased triglyceride levels (Table V).

Histopathological findings. 10 of the 11 rats fed a special atherogenic diet were found to have moderate to severe atherosclerotic lesions of their coronary arteries characterized by thickening of the tunica intima with foam cell accumulation and fibrous proliferation (Fig. $8 \mathrm{~A}$ ). The tunica intima of the affected coronary arteries contained many oil red 0 -stainable lipid droplets and exhibited increased deposition of acid-mucopolysaccharide when stained with alcian blue, and von Kossa's method revealed calcification and partial rupture of the internal elastic lamina. On the other hand, atherogenic diet-fed

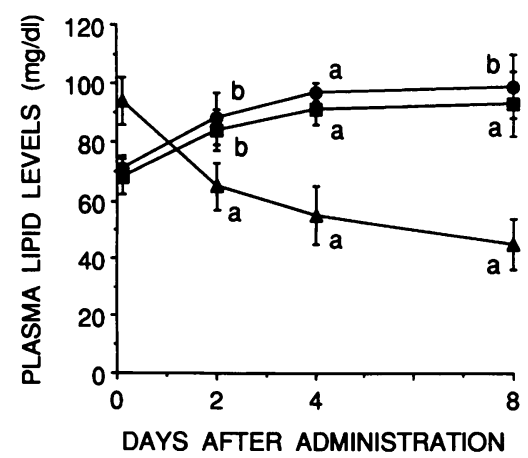

Figure 6. Plasma lipid levels after repeated administration of NO1886 in normal rats. NO-1886 was administered to normal rats in a daily dose of $25 \mathrm{mg} /$ $\mathrm{kg} \mathrm{BW}$ for 2,4 , and 8 d. Blood samples were collected $4 \mathrm{~h}$ after NO1886 administration. Data are expressed as means $\pm \mathrm{SD}(n=6)$ : cholesterol (•), HDL

cholesterol $(\square)$, triglycerides $(\Delta)$. Significantly different from the respect :e values in control rats: ${ }^{\mathrm{a}} P<0.01,{ }^{\mathrm{b}} P<0.01$.

$$
\text { NO-1886 }
$$

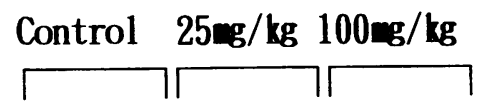

LPL

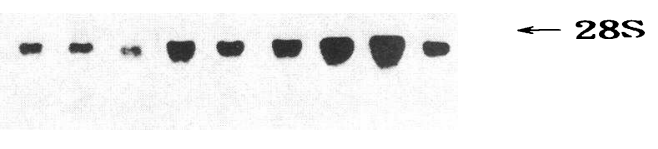

\section{$\beta$-actin}

Figure 7. Northern blot analysis of adipose tissue total RNA extract using a cDNA for rat LPL. Rats were divided into three groups and each group included three animals. Rats fasted overnight were administered NO-1886 in doses of either 25 or $100 \mathrm{mg} / \mathrm{kg} \mathrm{BW}$. Rats of control group received $5 \%$ gum arabic a diluent of the compound. $4 \mathrm{~h}$ later, the animals were killed by exsanguination under sodium pentobarbital anesthesia. Total RNA was prepared from the epididymal adipose tissue of the individual rats using the method described in Methods, and $4 \mu \mathrm{g}$ of total RNA was electrophoresed in each single lane. The positions of ribosomal RNA are indicated by arrows.

NO-1886-treated rats had only very mild to moderate lesions (Fig. $8 \mathrm{~B}$ ).

To represent the data statistically, we examined $\sim 10$ coronary arteries at random and classified the severity of coronary artery sclerosis into five grades on the basis of the extent of the atherosclerotic lesions. The results are summarized in Table VI. Higher doses of NO-1886 produced greater suppression of the development of atherosclerotic lesions of the coronary arteries $(P<0.01$, by two-way cumulative chi-square test $)$. To further define the relative contribution of HDL cholesterol, nonHDL cholesterol (total cholesterol - HDL-C), and triglycerides to protection from coronary artery sclerosis, multiple regression analysis was performed. The severity of coronary artery sclerosis was assessed on the basis of foam cell accumulation and graded as follows: " 1 " for grade 1, "2" for grade 2, " 3 " for grade 3, "4" for grade 4, and " 5 " for grade 5 . The results showed that plasma HDL cholesterol was the most powerful protector (standard regression coefficient $[\beta]=-0.595, P$ $=0.003$, multiple correlation coefficient $[R]=0.599$ ). Nor mal control rats had no atherosclerotic lesions of the coronary arteries.

\section{Discussion}

In this paper, we have described a new compound that increases tissue LPL activity in rats, resulting in a significant reduction in plasma triglyceride levels accompanied by a concomitant rise in HDL cholesterol. NO-1886 was shown to increase LPL enzyme mass in postheparin plasma and LPL mRNA activity in adipose tissue. Long-term administration of NO-1886 significantly suppressed the development of coronary artery sclerosis in vitamin $D_{2}$-treated, cholesterol-fed rats.

LPL plays a central role in the catabolism of triglyceriderich lipoproteins. Single doses of NO-1886 caused a marked increase of postheparin plasma LPL activity in normal rats, and the increase was dose dependent. This increase was confirmed when repeated doses of NO-1886 were administered. The increase in postheparin plasma LPL is thought to be a reflection of the increases in LPL activity in adipose tissue, the 


\begin{tabular}{|c|c|c|c|c|c|}
\hline \multirow[b]{2}{*}{ Groups } & \multirow{2}{*}{$\begin{array}{l}\text { No. of } \\
\text { animals }\end{array}$} & \multirow[b]{2}{*}{ BW } & \multicolumn{3}{|c|}{ Plasma lipids } \\
\hline & & & Cholesterol & HDL-C & Triglycerides \\
\hline & & $g$ & & $m g / d l$ & \\
\hline \multicolumn{6}{|l|}{ Atherosclerotic rats } \\
\hline Control & $(10)$ & $237 \pm 11$ & $809 \pm 1397$ & $204 \pm 26 \square$ & $72 \pm 17$ \\
\hline N0-1886 $3 \mathrm{mg} / \mathrm{kg}$ & (5) & $239 \pm 9$ & $724 \pm 117$ & $249 \pm 25]_{*}$ & $54 \pm 9]_{\ddagger}$ \\
\hline $\mathrm{N} 0-188630 \mathrm{mg} / \mathrm{kg}$ & $(10)$ & $240 \pm 19$ & $977 \pm 103^{-}$ & $360 \pm 31 \longrightarrow_{\S}$ & $52 \pm 12 \square *$ \\
\hline
\end{tabular}

Data are expressed as means \pm SD. Significantly different from the value in the respective control rats: ${ }^{*} P<0.01,{ }^{\ddagger} P<0.05,{ }^{8} P<0.001$.

myocardium, and skeletal muscle. In adipose tissue, both heparin-releasable LPL and residual LPL were higher in NO-1886treated rats than in controls, and thus total LPL activity in the tissue was certainly increased by the compound. In the LPL expression studies, NO-1886 was demonstrated to increase mRNA activity in adipose tissue, one of the major LPL producing tissues, indicating that the compound increases tissue LPL synthesis. The compound had no effect on the activity of HTGL, the enzyme mediating the catabolism of remnant lipoproteins by the liver (18).

The reduction in plasma triglyceride levels after single and repeated doses of NO-1886 is a consequence of elevated LPL activity. In a separate series of experiments, we found that the triglyceride synthesis rate was not diminished in rats treated with NO-1886 (data not shown). Another remarkable change occurring after NO-1886 administration was a marked elevation of plasma $\mathrm{HDL}$ cholesterol, especially $\mathrm{HDL}_{2}$ cholesterol. Previous reports have clearly demonstrated that enhanced lipolysis of triglyceride-rich lipoproteins results in an increase in $\mathrm{HDL}_{2}$ particles, thus a precursor-product relationship exists between the two $(6,19)$. Our protamine sulfate study provided direct evidence that the increase in LPL activity elevates HDL cholesterol level. The finding that the NO-1886-treated rats exhibited marked elevation of HDL cholesterol levels is of great interest. In humans, the transfer of cholesterol from newly formed $\mathrm{HDL}_{2}$ particles to VLDL is mediated by cholesterol ester transfer protein (20). Rats, however, lack cholesterol ester transfer protein (21), and because of this number of HDL particles following enhanced VLDL degradation by LPL was increased and accumulated in the circulation, resulting in a marked elevation of HDL cholesterol. The increases in plasma total cholesterol are obviously a result of the increases in $\mathrm{HDL}_{2}$, and there was no change in cholesterol in the LDL fraction after NO-1886 administration.

Of particular importance is that long-term administration of NO-1886 to rats with experimental atherosclerosis significantly inhibited the development of atherosclerotic lesions in the coronary arteries. This effect was probably not due to LPL per se but the consequence of a high concentration of HDL induced by LPL. A number of epidemiological studies have demonstrated an inverse association between plasma HDL levels and the development of coronary artery disease $(22,23)$.
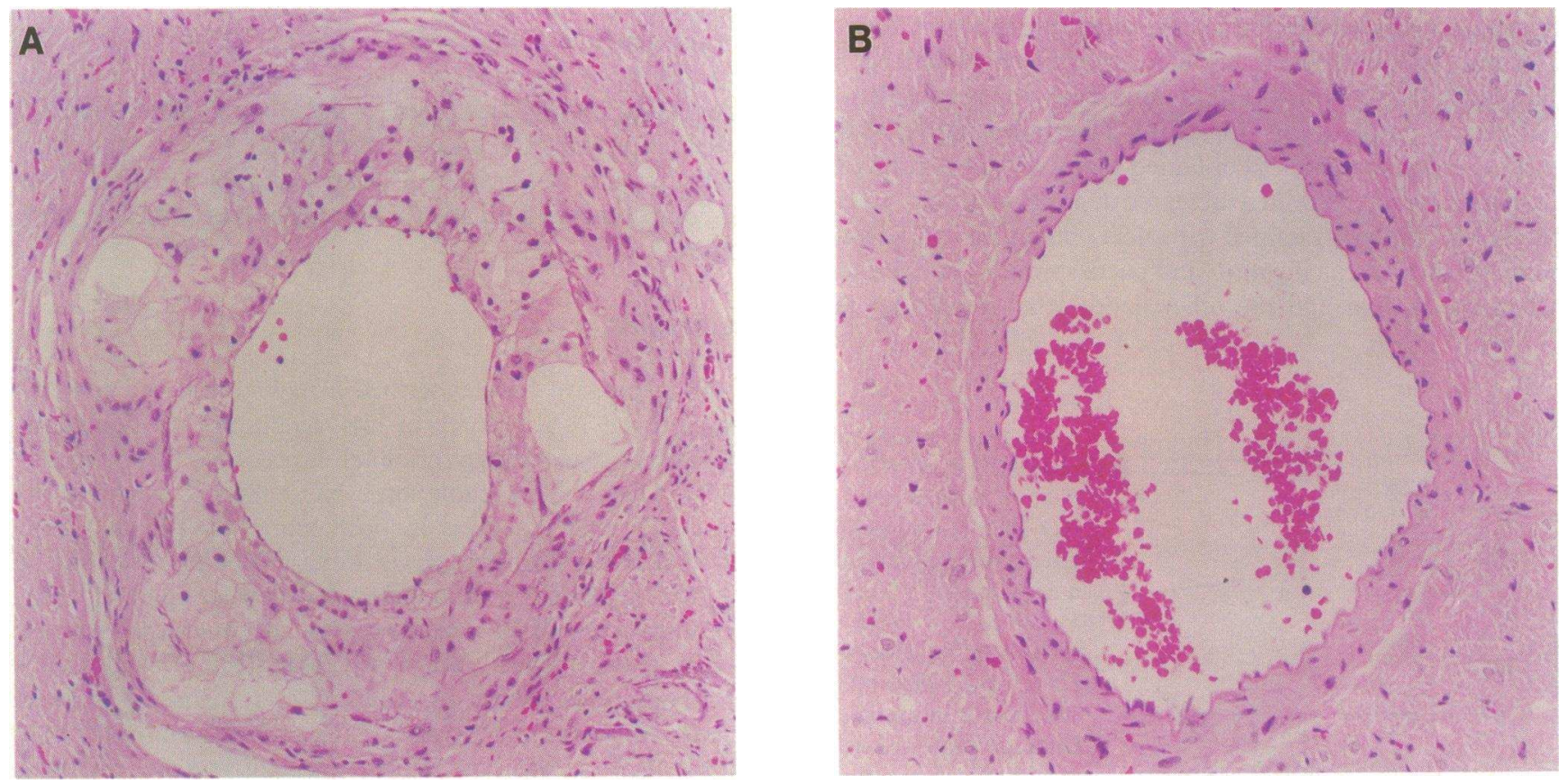

Figure 8. $(A)$ Coronary artery section stained with hematoxylin and eosin, showing marked thickening of tunica intima with foam cell accumulation and fibrous proliferation from an atherogenic diet-fed rat. Magnification, 175. (B) Section of a corresponding portion of a coronary artery from an atherogenic diet-fed, NO-1886 (30 mg/kg)-treated rat showing no atherosclerotic lesions. Magnification, 231. 


\begin{tabular}{|c|c|c|c|c|}
\hline \multirow[b]{2}{*}{ Histopathological Findings } & \multirow[b]{2}{*}{$\begin{array}{c}\text { Grade of atherosclerotic } \\
\text { lesions }\end{array}$} & \multirow[b]{2}{*}{$\begin{array}{l}\text { Atherogenic diet- } \\
\text { fed controls } \\
(n=11)\end{array}$} & \multicolumn{2}{|c|}{$\begin{array}{l}\text { Atherogenic diet-fed, } \\
\text { N0-1886-treated rats }\end{array}$} \\
\hline & & & $\begin{array}{l}3 \mathrm{mg} / \mathrm{kg} \\
(n=5)\end{array}$ & $\begin{array}{c}30 \mathrm{mg} / \mathrm{kg} \\
(n=11)\end{array}$ \\
\hline Thickening of the tunica intima & 1 & $1 / 11^{*}$ & $1 / 5$ & $5 / 11$ \\
\hline characterized by foam cell & 2 & $1 / 11$ & $2 / 5$ & $3 / 11$ \\
\hline accumulation and fibrous & 3 & $2 / 11$ & $0 / 5$ & $3 / 11$ \\
\hline \multirow[t]{2}{*}{ proliferation } & 4 & $6 / 11$ & $2 / 5$ & $0 / 11$ \\
\hline & 5 & $1 / 11$ & $0 / 5$ & $0 / 11$ \\
\hline
\end{tabular}

\begin{abstract}
* The number of rats with lesions/the number of rats examined. The severity of the atherosclerotic lesions was evaluated by examining $\sim 10$ coronary arteries and classifying them into five grades on the basis of the extent of the atherosclerotic lesions: grade 1: no atherosclerotic lesions in any of the coronary arteries examined; grade 2 : very mild ( $<25 \%$ of the area affected) atherosclerotic changes in a few coronary arteries; grade 3 : mild (25-49\%) atherosclerotic changes in several coronary arteries; grade 4: moderate (50-74\%) changes in almost all coronary arteries, and grade 5: severe ( $\geqq 75 \%)$ atherosclerotic changes in all coronary arteries examined.
\end{abstract}

Very recently, two different groups of investigators have demonstrated an inhibitory effect of high HDL on the development of atherosclerotic lesions, i.e., Badimon et al. (24), who repeatedly administered HDL to cholesterol-fed rabbits, and Rubin et al. (25), who used transgenic mice with high apolipoprotein A I and HDL levels. The results of multiple regression analysis in our study also suggest that HDL cholesterol is a strong protector against coronary artery sclerosis. Thus, maneuvers that increase HDL cholesterol levels might be expected to prevent the development of atherosclerotic lesions, and NO-1886 is a compound with just such an action.

In summary, we have described a compound with an action which potently increases LPL activity with resulting elevation in HDL cholesterol levels. Long-term administration of this compound significantly protected against the development of atherosclerotic lesions in the coronary arteries of rats fed an atherogenic diet.

\section{Acknowledgments}

We thank Drs. Kazuyoshi Miyata, Yasuo Shoji, Yoshihiko Tsuda (Department of Organic Chemistry), Eiji Uesaka, and Chieko Naba (Department of Pharmacology), New Drug Research Laboratory, Otsuka Pharmaceutical Factory, Inc., for their cooperation. We also thank Drs. Nobuhiro Yamada and Takanori Gotoda, Third Department of Internal Medicine, University of Tokyo, for their valuable comments.

\section{References}

1. Austin, M. A. 1991. Plasma triglyceride and coronary heart disease. Arterio scler. Thromb. 11:2-14.

2. Lapidus, L., C. Bengtsson, O. Lindquist, J. A. Sigurdsson, and E. Rybo. 1985. Triglyceride: main lipid risk factor for cardiovascular disease in woman? Acta Med. Scand. 217:481-489.

3. Castelli, W. P. 1986. The triglyceride issue: a view from Framingham. Am. Heart J. 112:432-437.

4. Fontbone, A., E. Eschwége, F. Cambien, J. L. Richard, P. Ducimetiere, N. Thibult, J. M. Warnet, J. R. Claude, and G. E. Rosselin. 1989. Hypertriglyceridemia as a risk factor of coronary heart disease mortality in subjects with impaired glucose tolerance or diabetes. Results from the 11-year follow-up of the Paris Prospective Study. Diabetologia. 32:300-304.

5. West, K. M., M. M. S. Ahuja, P. H. Bennett, A. Czyzyk, O. M. De Acosta, J. H. Fuller, B. Grab, V. Grabauskas, R. J. Jarrett, K. Kosaka, et al. 1983. The role of circulating glucose and triglyceride concentrations and their interactions with other risk factors as determinants of arterial disease in nine diabetic population samples from the WHO multinational study. Diabetes Care. 6:361-369.

6. Patsch, J. R., A. M. Gotto, Jr., T. Olivecrona, and S. Eisenberg. 1978.
Formation of high density lipoprotein -like particles during lipolysis of very low density lipoproteins in vitro. Proc. Natl. Acad. Sci. USA. 75:4519-4523.

7. Bajwa, G. S., L. M. Morrison, and B. H. Ershoff. 1971. Induction of aortic and coronary athero-arteriosclerosis in rats fed a hypervitaminosis D, cholesterolcontaining diet. Proc. Soc. Exp. Biol. Med. 138:975-982.

8. Page, I. H., and H. B. Brown. 1952. Induced hypercholesterolemia and atherogenesis. Circulation. 6:681-687.

9. Havel, R. J., H. A. Eder, and J. H. Bragdon. 1955. The distribution and chemical composition of ultracentrifugally separated lipoproteins in human serum. J. Clin. Invest. 34:1345-1353.

10. Murase, T., and H. Uchimura. 1980. A selective decline of post-heparin plasma hepatic triglyceride lipase in hypothyroid rats. Metab. Clin. Exp. 29:797801.

11. Gotoda, T., N. Yamada, M. Kawamura, K. Kozaki, N. Mori, S. Ishibashi H. Shimano, F. Takaku, Y. Yazaki, Y. Furuichi, and T. Murase. 1991. Heterogeneous mutations in the human lipoprotein lipase gene in patients with familial lipoprotein lipase deficiency. J. Clin. Invest. 88:1856-1864.

12. Mori, N., T. Murase, N. Yamada, N. Arakawa, and F. Takaku. 1984. Wide variations of plasma triglyceride concentrations in guinea pig. Lipids. 19:978-981.

13. Murase, T., N. Yamada, and F. Matsuzaki. 1981. The in vitro effect of growth hormone on adipose tissue lipoprotein lipase in rats. Life Sci. 28:199-201.

14. Salaman, M. R., and D. S. Robinson. 1966. Clearing factor lipase in adipose tissue. Biochem. J. 99:640-647.

15. Chomczynski, P., and N. Sacchi. 1987. Single-step method of RNA isolation by acid guanidium thiocyanate-phenol-chloroform extraction. Anal. Biochem. 162:156-159.

16. Sambrook, J., E. F. Fritsch, and T. Maniatis. 1989. Molecular Cloning. Second edition. Extraction, purification and analysis of messenger RNA from eukaryotic cells. Cold Spring Harbor Laboratory, Cold Spring Harbor, NY. 1-87.

17. Kaye, J. P., and D. J. Galton. 1975. Triglyceride-production rates in patients with type-IV hypertriglyceridemia. Lancet. i:1005-1007.

18. Murase, T., and H. Itakura. 1981. Accumulation of intermediate density lipoprotein in plasma after intravenous administration of hepatic triglyceride lipase antibody in rats. Atherosclerosis. 39:293-300.

19. Taskinen, M., and E. A. Nikkila. 1981. High density lipoprotein subfractions in relation to lipoprotein lipase activity of tissues in man-evidence for reciprocal regulation of $\mathrm{HDL}_{2}$ and $\mathrm{HDL}_{3}$ levels by lipoprotein lipase. Clin. Chim. Acta. 112:325-332.

20. Tall, A., T. Swenson, C. Hesher, and E. Granet. 1987. Mechanism of fascilitated lipid transfer mediated by plasma lipid transfer proteins in plasma lipoproteins. New Compr. Biochem. 14:277-297.

21. Tall, A. R. 1986. Plasma lipid transfer proteins. J. Lipid Res. 27:361-367.

22. Gorden, D. J., and B. M. Rifkind. 1989. High-density lipoprotein: the clinical implications of recent studies. $N$. Engl. J. Med. 321:1311-1316.

23. Frick, M. H., O. Elo, K. Haapa, O. P. Heinonen, P. Heinsalmi, P. Helo, J. K. Huttunen, P. Kaitaniemi, P. Koskinen, V. Manninen, et al. 1987. Helsinki heart study: primary-prevention trial with gemfibrozil in middle-aged men with dyslipidemia. N. Engl. J. Med. 317:1237-1245.

24. Badimon, J. J., L. Badimon, and V. Fuster. 1990. Regression of atherosclerotic lesions by high density lipoprotein plasma fraction in the cholesterol-fed rabbit. J. Clin. Invest. 85:1234-1241.

25. Rubin, E. M., R. M. Krass, E. A. Spangler, J. G. Verstuyft, and S. M. Cliff. 1991. Inhibition of early atherogenesis in transgenic mice by human apolipoprotein AI. Nature (Lond.). 353:265-267. 